\title{
The Symbolic Meaning of the Role of Bundo Kanduang in the Badatuk Ceremony at the Gadang House
}

\author{
Rosalinda Wiemar ${ }^{1}$, Susy Irma Adisurya ${ }^{2}$, Resky Annisa Damayanti ${ }^{3}$ \\ \{rosalinda_wiemar@trisakti.ac.id ${ }^{1}$ \} \\ Doctoral Program in Visual Art and Design, Institut Teknologi Bandung. Indonesia ${ }^{1}$, Interior \\ Design Department. Faculty of Art and Design. Universitas Trisakti Indonesia ${ }^{2,3}$
}

\begin{abstract}
Abstrak. Minangkabau is an indigenous ethnic group of West Sumatera. The adopted kinship of this ethnic group is matrilineal, which is a lineage based on mother's ethnicity. In this ethnic group, a woman who is married, wise, and considered as elder, is called Bundo Kanduang. Badatuk ceremony is a ceremony to select Minangkabau tribe leader, and in this event, the role of Bundo Kanduang is not only functionally vital, but also has an implicit symbolic meaning. Considering the importance of the role of Bundo Kanduang, it is considered necessary to acknowledge the representation of symbolic meaning of Bundo Kanduang on activities conducted in the Gadang House. The method utilized in this research is an ethnographic method with qualitative analysis approach. In this research, we discovered that the symbolic meaning of the role of Bundo Kanduang is reflected in the interior of Gadang House that is adjusted to facilitate Bundo Kanduang activities on Badatuk ceremony.
\end{abstract}

Keywords: Badatuk ceremony; Bundo Kanduang; Minangkabau; matrilineal.

\section{Introduction}

Indonesian Republic is an archipelago country that possesses thousands of islands, and each of these islands possesses their own unique cultures, which makes Indonesia rich of local cultures. The local development and improvement process along with its human resources require cultural data and information as a system, which can be utilized as guidance to understand each and every society behavioral pattern. Because of that, it is important to possess adequate knowledge of society role and behavior in certain culture to understand the environment also visible and experienced symptoms, to create suitable planning and select the necessary action to provide response towards challenges faced in the environment.

Minangkabau ethnic groups in West Sumatera possess cultural values that are presented in their local values, norms, and rules that form social system of the society. The adopted values and norms possess pattern and variety of uniformity within the society that practice them. The social system in Minangkabau ethnic group is categorized based on their age, education, social level, sex, etc. In indigenous Minangkabau area, the society is bound with their bloodline, kinship and area of origins (locally known as ulayat). Social system based on sex is categorized to male and female; each of them has their own unique positions and roles. Females, based on their customary rules are considered as limpapeh rumah nan gadang, which 
means that the roles to determine their bloodline and inheritance is decided through the mother side. The role of females known as Bundo Kanduang is vital because the females' position in ensuring their generation sustainability [1].

The role of Bundo Kanduang is different than any other Indonesian women, especially in subject of matrilineal blood line. That is why, females that are wise, motherly, and have the ability to create balance in their families in Minangkabau ethnic group are called as Bundo Kanduang. However, there are also similarities with the role of regular Indonesian women, which is as housewives that help their husbands in various type of activities [2].

The position and role of women in Minangkabau are regulated in their culture. Minangkabau culture regulates women's role and position in social system, kinship system, bloodline, boundaries of social interaction between relatives, principles of bloodline relationships, position of inheritance and its inheriting system, because they are bound by matrilocal marriage system.

Gadang House as a custom building collectively owned by the tribe is the main facility to conduct their daily activities and cultural ceremonies. Bundo Kanduang as the main figure of the tribe is regularly involved in every activity inside Gadang House. However, even though women act as main figures, men are still appointed as leaders. The group of tribal leaders is referred to as the "adat leader". In adat, a penghulu is a leader who must be accountable to the community, particularly to the nephews he leads [3]. The peak of the leader of the penghulu is called Datuk, therefore the ceremony for the appointment of tribal leaders is called the Badatuk ceremony.

This ceremony is one of the most important events that involved large scope of society in Minangkabau. In this ceremony, we can clearly observe the role of Bundo Kanduang as representatives of women and the role of men as leaders of the ethnic group. There are a number of articles that discuss on matrilineal system, Gadang House, and Bundo Kanduang. However, these articles are unable to specifically explain the symbolic meaning of the role of Bundo Kanduang in the establishment of Gadang House interior, especially during Badatuk ceremony. Besides that, Minangkabau tradition are mostly conducted orally, which drives concerns that the role will be reduced, shifted, or even diminished along with the advance of society. Based on that, this research is aimed to highlight Minangkabau culture that is rich with symbolic meanings and can be passed to the next generation.

\subsection{Bundo Kanduang and Badatuk Ceremony}

Minangkabau culture teaches us to cultivate respect and honor women in our daily life, through the ethnic group matrilineal system that point them as the center of the bloodline. A grown woman that has married, wise, understand Minangkabau culture, and has the ability to maintain balance within the family is called as Bundo Kanduang. Bundo Kanduang is given certain privileges and exceptions than the males of Minangkabau, to ensure that they are protected from actions that might lower the noble position of Bundo Kanduang. Because of their important role in the society, the presence of Bundo Kanduang alongside of men as leaders of the ethnic group, both on their daily life and cultural ceremonies, especially Badatuk ceremony as a grand ceremony, is vital because the ceremony can represent Minangkabau culture as a whole.

Broadly speaking, the role of Bundo Kanduang in Minangkabau culture involves duties and obligations which consist of four basics footholds of women roles according to Minangkabau culture [4] which are: 
1. Manuruik alua nan luruih (to follow a straight path), the meaning of alua is that every Minangkabau customary provisions are based on its own terms and conditions.

2. Manampua jalan nan pasa (to follow the regular path), according to Minangkabau culture, this basis contains figurative meaning that every path chosen by Bundo Kanduang is a way to achieve goals, both in this life and the afterlife.

3. Mamaliharo harato pusako (to preserve inheritance), based on Minangkabau culture, harto pusako is a treasure determined by their culture. This treasure must be protected so it would never to move to another county, except when it is required by the public to build public facilities, and the decision must be taken through discussion (musyawarah)

4. Mamaliharo anak dan kemenakan (to preserve future generations), on a broad scale this is the main obligation and duty of Bundo Kanduang in Minangkabau. The implementation is summarized in a traditional proverb: Manuruah babuek baik, malarang babuek nan mungka (directing people to do good and to avoid wickedness).

Badatuk ceremony is intended to appoint tribe leader. Generally, the event is divided into three parts which are: pre-event, the event, and post-event. Every activity involves both women and men women are led by Bundo Kanduang meanwhile the men are led by Penghulu (tribe leader, under coordination of a Datuk) The following table summarizes the series of Badatuk ceremony in relation with the obligation and duty of Bundo Kanduang in the event.

Tabel 1. Series of Badatuk ceremony in relation with symbolic meaning along with the obligation and duty of Bundo Kanduang.

\begin{tabular}{|c|c|c|}
\hline & Activities conducted & $\begin{array}{c}\text { Obligation and Duty of Bundo } \\
\text { Kanduang according to } \\
\text { traditional proverb }\end{array}$ \\
\hline \multicolumn{3}{|c|}{ I. } \\
\hline 1 & $\begin{array}{l}\text { All Penghulu that are sepayung (penghulu from the } \\
\text { same tribe) and every group of the penghulu which will } \\
\text { be replaced, involved in a discussion. The women are } \\
\text { preparing the area and the food required for the activity }\end{array}$ & $\begin{array}{l}\text { Manuruik alua nan lurui } \\
\text { (to follow a straight path) } \\
\text { Manampua jalan nan pasa } \\
\text { (to follow the regular path). } \\
\text { Mamaliharo harato pusako } \\
\text { (to preserve inheritance). }\end{array}$ \\
\hline 2 & $\begin{array}{l}\text { Presenting discussion result to the mother, this will be } \\
\text { answered with a satisfying answer towards the group of } \\
\text { penghulu. Together, the group of penghulu will visit } \\
\text { penghulu nagari to ask for permission to prepare a } \\
\text { "place for penghulu." }\end{array}$ & $\begin{array}{l}\text { Manuruik alua nan lurui } \\
\text { (to follow a straight path) } \\
\text { Manampua jalan nan pasa } \\
\text { (to follow the regular path). }\end{array}$ \\
\hline 3 & $\begin{array}{l}\text { Preparing a "place for penghulu" in the middle of } \\
\text { Gadang house along with traditional clothing and } \\
\text { equipment, which is conducted by the women the tribe. }\end{array}$ & $\begin{array}{l}\text { Mamaliharo harato pusako } \\
\text { (to preserve inheritance). } \\
\text { Mamaliharo anak dan kemenakan } \\
\text { (to preserve future generations) }\end{array}$ \\
\hline \multirow[t]{2}{*}{4} & $\begin{array}{l}\text { Conducting appointment discussion which is attended } \\
\text { by all penghullu in the area. The new appointed } \\
\text { Penghulu wear his traditional dress with no destars. } \\
\text { The women and men prepare the meal. }\end{array}$ & $\begin{array}{l}\text { Manuruik alua nan lurui } \\
\text { (to follow a straight path) } \\
\text { Manampua jalan nan pasa } \\
\text { (to follow the regular path). } \\
\text { Mamaliharo harato pusako } \\
\text { (to preserve inheritance). }\end{array}$ \\
\hline & The Event & \\
\hline 5 & $\begin{array}{l}\text { The newly appointed Penghulu respectfully ask his } \\
\text { mother that is seated in a pangka near penghulu of his } \\
\text { tribe. He then gives bow from the end towards the } \\
\text { middle, which is called as "sembah marewai", and bow }\end{array}$ & $\begin{array}{l}\text { Manuruik alua nan lurui } \\
\text { (to follow a straight path) } \\
\text { Manampua jalan nan pasa } \\
\text { (to follow the regular path). }\end{array}$ \\
\hline
\end{tabular}




\begin{tabular}{|c|c|c|}
\hline & Activities conducted & Obligation and Duty of Bundo \\
\hline & $\begin{array}{l}\text { to all penghulu in the area and the imam khatib. By } \\
\text { doing so, the newly appointed Penghulu is officially } \\
\text { "seat together" with all Ninik Mamak in the area. The } \\
\text { order of offerings has a meaning that the newly } \\
\text { appointed penghulu will cooperate, according the order } \\
\text { of the offerings (masak di pangka di tatiang ka ujung), } \\
\text { which means: cook at the base, ad presented at the end. } \\
\text { After this Penghulu is allowed to wear new destar. }\end{array}$ & $\begin{array}{l}\text { Mamaliharo harato pusako } \\
\text { (to preserve inheritance). }\end{array}$ \\
\hline 6 & $\begin{array}{l}\text { Someone from the tribe of the new Penghulu stand near } \\
\text { the lintel presents a speech that consist of advices for } \\
\text { the new Penghulu related with his title and his } \\
\text { obligations towards his family. One of the wise man } \\
\text { will answer it with a confirmation. After that custom } \\
\text { money is given to the rightful. } \\
\text { The women and men prepare the equipment and food. }\end{array}$ & $\begin{array}{l}\text { Manuruik alua nan lurui } \\
\text { (to follow a straight path) } \\
\text { Manampua jalan nan pasa } \\
\text { (to follow the regular path). } \\
\text { Mamaliharo harato pusako } \\
\text { (to preserve inheritance). }\end{array}$ \\
\hline \multirow[t]{2}{*}{7} & $\begin{array}{l}\text { After eating and drinking activities, a prayer to ask for } \\
\text { safety is held. }\end{array}$ & $\begin{array}{l}\text { Manuruik alua nan lurui } \\
\text { (to follow a straight path) } \\
\text { Manampua jalan nan pasa } \\
\text { (to follow the regular path } \\
\text { Mamaliharo harato pusako } \\
\text { (to preserve inheritance). } \\
\text { Mamaliharo anak dan kemenakan } \\
\text { (to preserve future generations) }\end{array}$ \\
\hline & Committee disbandmer & (puntuang parun) \\
\hline 8 & $\begin{array}{l}\text { On the next day, a discussion to disband the committee } \\
\text { is held while also conduct further discussion on } \\
\text { unfinished business. }\end{array}$ & $\begin{array}{l}\text { Manuruik alua nan lurui } \\
\text { (to follow a straight path) } \\
\text { Manampua jalan nan pasa } \\
\text { (to follow the regular path) } \\
\text { Mamaliharo harato pusako } \\
\text { (to preserve inheritance). } \\
\text { Mamaliharo anak dan kemenakan } \\
\text { (to preserve future generations) }\end{array}$ \\
\hline
\end{tabular}

\subsection{Spaces on Gadang House Interior}

We understand that there is a great relation between spaces and activities, in this case is the relation of a culture and the human that practice the culture. Spaces such as house, village, and the environment act as facilities for individual and social activities at all time, and transforms into symbolic expressions of the people's culture and values. Based on that, the artificial environment is a product of a reciprocal relationship between groups that inhabit their living spaces.

Amos Rapoport, a researcher concentrated on architecture and anthropology, mentioned that basically there is a relatedness or reciprocal relationship between space and human or society that utilize the space. This will drive specific differences in specific areas, which represents humane cultural diversity. Because of that, space has different and plural value and meanings, which depends on the behavior and lifestyle of an individual or society that utilize the space. In another word, different norm, views of life or culture aspects will result different conception and formation of space [5]. This relationship is illustrated in Figure 1. The space context as presented by Rapoport is known more as setting, a term that represents interaction between human and space. The role of Bundo Kanduang as a part of Minangkabau culture that 
possesses deep symbolic meaning is expressed in forms of activities practice in Gadang House. Because of that, the role values of Bundo Kanduang in Minangkabau culture, especially on Badatuk ceremony is an interaction shown with the formation of Gadang House interior.

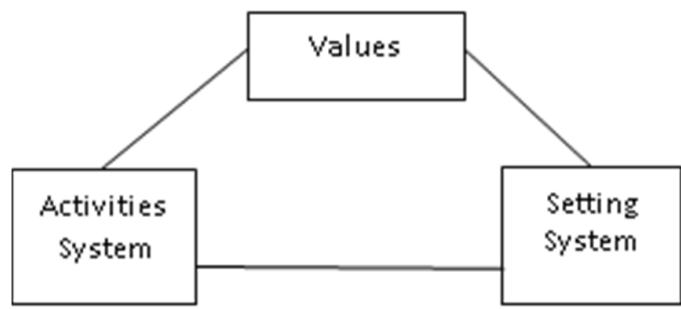

Fig. 1. Triangular relationship between Values - Activity System - Setting System [6]

In his book Human Aspects of Urban Form, Rapoport explains about the reciprocal relationship by picturing the relationship starting from culture aspect that unraveled into views of life, and setting system [7]. Setting is a vessel where activities are performed, meanwhile activities are physical form of body movement. In form of system setting or series of activities that embodies lifestyle. On the other side, lifestyle itself is a selection of an individual and this selection is based on values adopted by the individual. Values are standard used by an individual to pick a goal and to determine life priority. Value will always be based on views of life adopted by the individual. All these sequences will be sourced on the culture adopted in the area where the individual comes from [6].

\section{Method}

\subsection{Scientific approach}

Scientific approach adopted in this research is a Culture Science, with ethnographic method and analyzed with a qualitative approach. The goal of ethnography is to analytically describe social scenes and social groups that represent mutual trust, practices, artifacts, knowledge and behaviors [8], [9]. Observation conducted on the researched site was practiced on a long period of time to understand daily activities and traditional ceremonies practiced in a number of Gadang Houses. The observation is conducted on artifacts found in Gadang House, practice mapping, information gathering and analysis.

This method is focused on the activities practiced by Gadang House occupants, especially the ones related with the role of Bundo Kanduang that possess symbolical values that are cosmologically represented in the interior of Gadang House. Based on Creswell [10], the research procedure with an ethnographic method is conducted with the following procedure: a. Conduct identification and location of culture sharing to be studied. Choose the right Gadang House. b. Describe the activities performed by the society that represents Minangkabau culture through interior of Gadang House in relation with the role of Bundo Kanduang, based on theoretical framework and literature data. c. Conduct studies on Gadang House occupants on Badatuk ceremony setting. d. Gather the necessary information from the field (fieldwork) through in-depth interview to obtain accurate answer and visual mapping. e. Produce data 
analysis and complete interpretation from the gathered source. f. Conduct detailed description compilation that contains participant and researcher perspectives.

\subsection{Data Collection Method}

Data collection method includes two data sources which are literature data and field data. Literature data connected with research topic are categorized into scientific field namely: space on interior, Minangkabau culture with discussion subs of Badatuk ceremony. Bundo Kanduang with discussion sub of conceptual content, textual and visual, related with task and responsibility, along with the activities performed in Gadang House and their relations with Badatuk ceremony. Field data was obtained from observation on participants, interview with selected informants according to the requirements and collection of artifacts. Observation was conducted inside Gadang House, during Badatuk ceremony, especially the role of Bundo Kanduang in the ceremony whether during preparation, implementation and postimplementation.

\subsection{Direct Mapping}

Direct mapping was conducted based on observation or based on notes. Mapping procedure consists of five basic elements namely: a. Basic sketch of the area or setting that will be observed. b. Create a clear definition of behaviors that will be observed. c. Create a clear time planning for observation activities. To gather data the required data of the role of Bundo Kanduang, interview was implemented on informants. d. Follow systematic procedure that must be conducted during observation.

\subsection{Data Category}

The collected data are categorized into two groups: a. Primary data, which are data directly obtained from the sources regarding general and specific Minangkabau culture, especially the ones related with Gadang House and Bundo Kanduang. b. Secondary data, which consists of data gathered from other parties. This secondary data act as supportive data that completes primary data. Data triangulation was conducted to understand complex, hard to decide problems, to produce views from various perspectives. Field data triangulation will be conducted through in-depth interview with a number of informants to obtain accurate data.

\subsection{Data Analysis}

Data analysis method is conducted through qualitative approach with descriptive analysis. The analysis describes more about the actual situations. During analysis process, comparative and contradictive techniques were utilized to identify patterns [9]. Conclusion was taken as a part of the whole research process and was verified during research activities were conducted.

\section{Results and Discussion}

One of the largest ceremonies that represent Minangkabau culture is Badatuk ceremony (Penghulu appointment). Although basically this ceremony is a ceremony led by men, the procession emphasizes the position of women amongst men. In this case, Bundo Kanduang 
plays a very important role. Each role has attributes that must be used, such as clothing, position, and space facilities in the rumah gadang [11]. Based on that, the stages of the ceremony should be carefully explained to acknowledge the role and activities of Bundo Kanduang and the role of men in the ceremony.

Generally, tribe leader substitution is not strictly scheduled on a clear time period, but rather conditional and flexible according to the tribe's needs or dynamic society situations and will only be held when the leader is considered unfit or passed away. The process of leader appointment is basically conducted on several stages, started from discussion (barundiang) by the members of the families (musyawarah saparuik), attended by leader's relatives (musyawarah sapayuang), and tribal discussion under suku nan ampek (musyawarah suku) and finally brought to Kerapatan Adat Nagari (KAN).

After these activities are performed, the event is held based on the tribe financial capability. Usually, leader appointment ceremony is conducted for three days, completed with art performances and buffalo slaughter feasts to entertain guests. All close relatives, family members and society members attend the ceremony, especially on the main event such as traditional speech that describes on the duty and responsibility of a leader. In this event the newly appointed leader promises to not break or conduct actions deviates cultural values in his government activities. Badatuk ceremony process is ended with a meeting between committee and the family which is called as puntuang parun. In this meeting, committee disbandment is conducted to discuss on certain things that should be finished. (Figure 2).

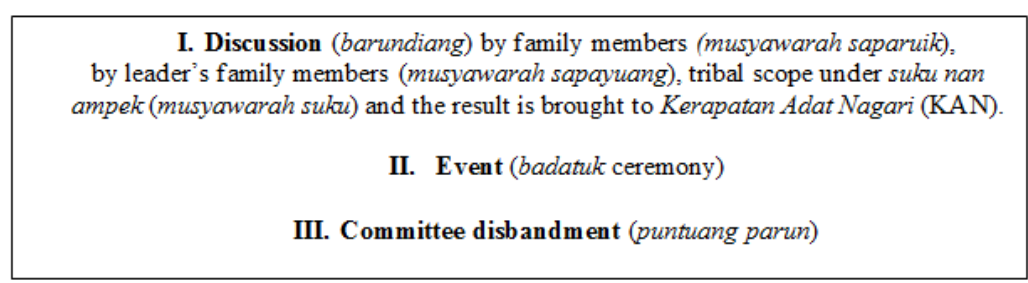

Fig. 2. Stages of Badatuk ceremony.

The following part discuss on the activity of Bundo Kanduang and men in Badatuk ceremony in Gadang House:

\subsection{Discussion (barundiang)}

Discussion conducted by family members (musyawarah saparuik), leader's family members (musyawarah sapayuang), and tribal scope under suku nan ampek (musyawarah suku) which finally brought to Kerapatan Adat Nagari (KAN). Discussion is led by men, but always involve women, especially Bundo Kanduang. 


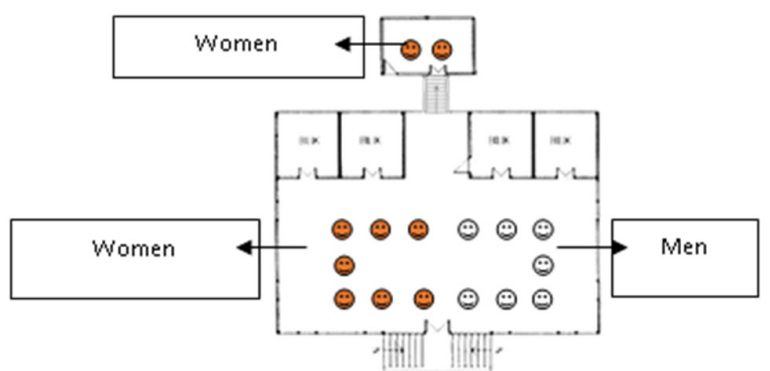

Fig. 3. Seating position during discussion

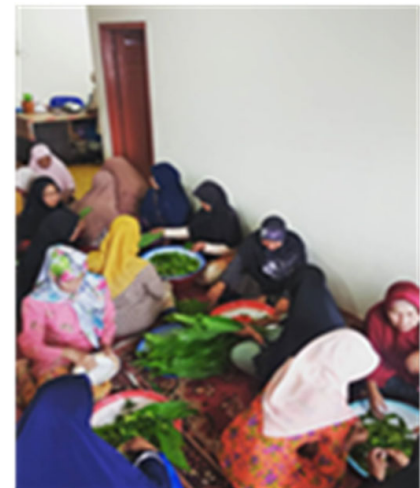

Fig. 4. Bundo Kanduang and women prepare food during discussion and ceremony [12]

At this stage, the role of Bundo Kanduang on duty and obligation line of Manuruik alua nan lurui based on Minangkabau culture is practiced with certain regulations and propriety. For example, even though Bundo Kanduang is a central figure of a tribe, the leadership still belongs to men. Even so, the opinion and suggestion of Bundo Kanduang is always considered and decision will be determined through collaborative discussion. This practice follows the regulation of Manampua jalan nan pasa, which states that every path should lead to a decent goal, and in the end will benefit them both in this life and the afterlife. On grand discussion, the men and women are separately seated in the house, where most of the women are located in the back part of the house such as kitchen, to help prepare everything and to make sure that the discussion can be conducted according to the regulation (Figure 3 ). This role is conducted by women in order to fulfill their role on Mamaliharo harato pusako which is to preserve their inheritance so it can be used to fulfill general needs after the discussion is finished. (Figure 4, $5)$.

\subsection{The Event}

The event is the main part of Badatuk ceremony. The procession is conducted based on pre-decided culture values and deals on previous discussions that involves women led by Bundo Kanduang and men led by tribe leader (penghulu). 


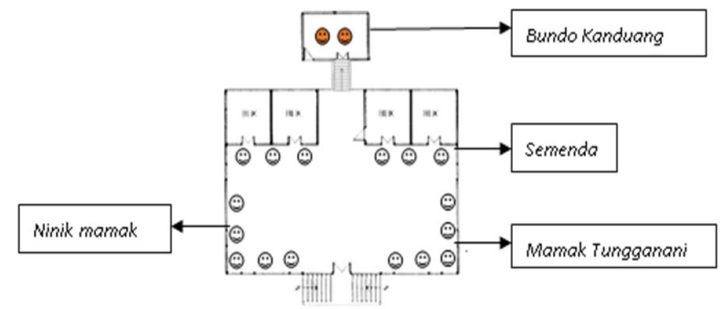

Fig. 5. During the ceremony, the men are seated in the living room meanwhile the women are in the back areas to prepare the event.

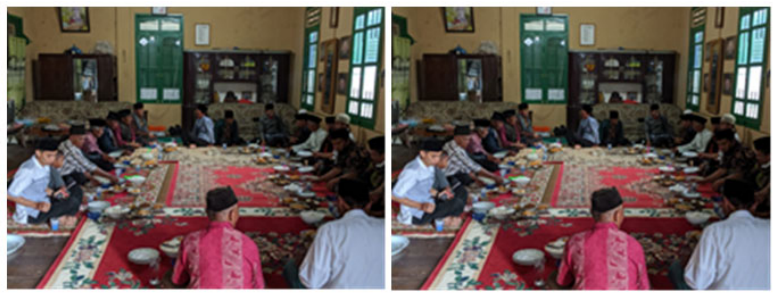

Fig. 6. Men and women are separately seated in the event and the children are seated next to their mothers.

At each step, women and men are placed in different time and space with different unique roles (Figure 5). Both groups are helping each other, complete each other, and follow the regulations to ensure decent life can be achieved within the tribe. On Badatuk ceremony, the women and men are separately placed, children are placed among group of women near to their mothers in order to fulfill function of Mamaliharo anak dan kemenakan. As shown in Figure 6, during feast, the women and men are separately seated, and the children are seated next to their mothers or their sisters.

\subsection{Committee disbandment (puntuang parun)}

In the end, the ceremony is closed with family gathering in form of discussion and feasts with the aforementioned seating formation, but on a different scale, according to the financial capability of the tribe that held the ceremony (Figure 7).
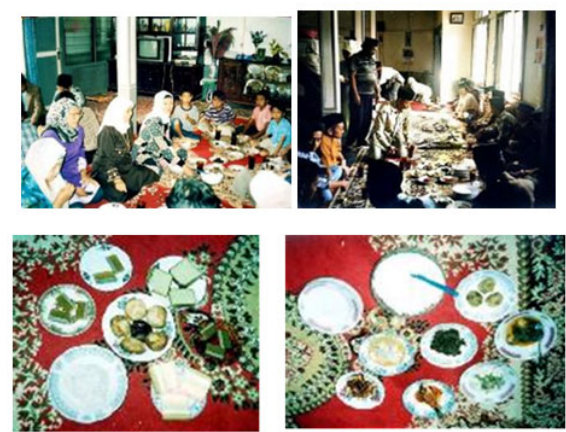

Fig. 7. Family gathering in form of discussion and feasts with the aforementioned seating formation 


\section{Conclusion}

There is a close relationship between space and activities, in this case is the spaces in Gadang House that related with its occupants and the role of Bundo Kanduang in Badatuk ceremony. The interior of Gadang House act as facility for individual activities and social behavior of Bundo Kanduang and the occupants of Gadang House. These spaces are also act as symbolic expression of the values and obligations of Bundo Kanduang as central figure of Minangkabau culture that adopts matrilineal kinship. Based on that, an artificial environment, in this case the Gadang House is a product built of reciprocal relationship generally between groups of users and their living spaces and Bundo Kanduang especially on Badatuk ceremony.

\section{Refferences}

[1] S. Hardono, A. Bahauddin, A. Abdullah, and N. Z. Maliki, "The Matrilineal Architectural Values on The Construction of The Minangkabau House," Dimens. J. Archit. Built Environ., vol. 41, no. 1, pp. 51-58, 2014.

[2] Bustami, The Position and Role of Women in the Culture of the Minangkabau Society. Jakarta: Departemen Pendidikan dan Kebudayaan, 1988.

[3] I. H. D. Penghulu and Rajo, Guidance of Penghulu, Bundo Kanduang, and Alua Pasambahan Cultural Speech in Minangkabau. Bandung: Remaja Rosdakarya Offset, 1994.

[4] I. H. D. Penghulu and Rajo, Pegangan Bundo Kanduang di Minangkabau. Bandung: CV Rosda, 1978.

[5] A. Rapoport, House Form and Culture. New Jersey: Prentice Hall, Inc, 1974.

[6] S. Triatmodjo, "Consensus and Desacralization of Space in the Yogyakarta Kauman Settlement," Dissertation, Jurusan Teknik Arsitektur, Fakultas Teknik, Universitas Gadjah Mada., 2010.

[7] A. Rapoport, Human Aspects of Urban Form. Oxford: Pergamon Press, 1980.

[8] M. D. LeCompte and J. P. Goetz, "Problems of Reliability and Validity in Ethnographic Research," Rev. Educ. Res., vol. 52, no. 1, pp. 31-60, 1982.

[9] P. D. Leedy, Practical Research. Columbus: Merrill, Ohio, 1997.

[10] J. W. Creswell and P. V. . Clark, Designing and Conducting Mixed Methods Research. California: Sage, Thousand Oaks, 2007.

[11] Ernatip and S. Devi, "The Position and Role of Bundo Kanduang in the Matrilineal Kinship System in Minangkabau," Balai Pelestarian Nilai Budaya Padang, Padang, pp. 80-97, 2014.

[12] S. Irma A, "Badatuk Ceremony at Sariak Village.” Bukittinggi. Sumatra Barat., 2019. 